\title{
Evidence of the effect of domicile on corporate average effective tax rates in the European Union
}

Citation for published version (APA):

Buijink, W. F. J., Janssen, J. B. P. E. C., \& Schols, Y. J. (2000). Evidence of the effect of domicile on corporate average effective tax rates in the European Union. METEOR, Maastricht University School of Business and Economics. METEOR Research Memorandum No. 049 https://doi.org/10.26481/umamet.2000049

Document status and date:

Published: 01/01/2000

DOI:

10.26481/umamet.2000049

Document Version:

Publisher's PDF, also known as Version of record

\section{Please check the document version of this publication:}

- A submitted manuscript is the version of the article upon submission and before peer-review. There can be important differences between the submitted version and the official published version of record.

People interested in the research are advised to contact the author for the final version of the publication, or visit the DOI to the publisher's website.

- The final author version and the galley proof are versions of the publication after peer review.

- The final published version features the final layout of the paper including the volume, issue and page numbers.

Link to publication

\footnotetext{
General rights rights.

- You may freely distribute the URL identifying the publication in the public portal. please follow below link for the End User Agreement:

www.umlib.nl/taverne-license

Take down policy

If you believe that this document breaches copyright please contact us at:

repository@maastrichtuniversity.nl

providing details and we will investigate your claim.
}

Copyright and moral rights for the publications made accessible in the public portal are retained by the authors and/or other copyright owners and it is a condition of accessing publications that users recognise and abide by the legal requirements associated with these

- Users may download and print one copy of any publication from the public portal for the purpose of private study or research.

- You may not further distribute the material or use it for any profit-making activity or commercial gain

If the publication is distributed under the terms of Article $25 \mathrm{fa}$ of the Dutch Copyright Act, indicated by the "Taverne" license above, 


\title{
Evidence of the effect of domicile on corporate average effective tax rates in the European Union
}

\author{
Willem Buijink* \\ Boudewijn Janssen* \\ Yvonne Schols*
}

version $1 / 9 / 2000$

MARC Working Paper MARC-WP/3/2000-11

* MARC, Faculty of Economics and Business Administration, Universiteit Maastricht, The Netherlands. This paper was written while the first author was a visiting professor at the Faculty of Applied Economics, UFSIA, University of Antwerp, Belgium. The authors thank the Dutch Ministry of Finance for providing financial support for the research in this paper. The usual caveat applies. 


\begin{abstract}
We estimate corporate average effective tax rates from financial statements for companies domiciled in European Union (EU) member states during 7 years from 1990 to 1996. Our objective is to compare the tax rate effectively experienced by companies with the corporate statutory tax rate in the EU country in which each company is domiciled. The difference between the corporate statutory tax rate and the financial statements based corporate average effective tax rate provides information on the magnitude of tax incentives provided by governments within the EU. These tax incentives come on top of the directly observable differences in statutory tax rates between EU member states. We find (i) that the use of tax incentives, over and above differences in statutory tax rates, differs substantially between EU member states (corporate domiciles) and (ii) that the provison of tax incentives does not have the effect of equalizing corporate effective tax rates between EU member states (corporate domiciles).
\end{abstract}




\section{Introduction}

We use consolidated financial statements to determine effective tax rates (ETRs) for companies domiciled in European Union (EU) member states. There already exist differences in statutory corporate tax rates (STRs) between EU countries. These differences are relatively easy to observe (see below). But EU countries also provide tax incentives ${ }^{1}$ to companies. To the extent that this happens, STRs do not provide a complete picture of (i) actual corporate tax burdens in EU countries and (ii) of differences in actual corporate tax burdens between companies domiciled in different EU countries. In this paper we attempt to determine the actual ETRs experienced by companies in EU countries using consolidated financial statement data for the recent 1990 - 1996 period. These ETRs provide a picture of both differences in STR ànd the provision of tax incentives between EU member states, i.e. of actual corporate tax burdens.

Such a picture is important because actual corporate tax burdens, which ETRs attempt to measure, are generally thought to be an important element in the 'competitive' position of a country, e.g. in terms of location decisions of companies ${ }^{2}$ or of founding rates of new companies. Also, actual corporate tax burdens are a constant item in discussions about tax competition between countries in general and, recently, between EU countries in particular. Knowledge about actual tax burdens is important for these discussions.

This paper is the first (we will discuss previous research in section 2) to measure ETRs using financial statements information for (listed) companies in all 15 current EU member states.

There are alternative approaches to measuring ETRs. However, the alternative approaches to measuring effective tax rates are (i) either case-based, i.e. not calculated for actual companies, or (ii) rely on assumption-based simulation for individual companies.

ETRs determined using financial statements, as in this paper, are firm-specific and require no simulation and underlying assumptions. They can also conveniently be used to make a distinction between permanent tax incentives and timing tax incentives ${ }^{3}$ provided by the EU member state governments to companies domiciled in their jurisdiction.

This paper is the first to use the Primark Worldscope financial statement data base in comparative international tax accounting research. Moreover, we provide an international comparison on a larger scale than previous research both for more countries and for a larger number of firms in each country.

Our findings are as follows. First, comparing EU member states on the basis of the difference between the statutory corporate income tax rate (STR) and the effective corporate 
income tax rate (ETR), taking into account permanent tax incentives, reveals considerable differences. That is, the use of tax incentives differed quite substantially between EU member states (corporate domiciles) in the recent 1990 to 1996 period. Second, we also find that the range of the ETR across EU member states is less centered than the statutory tax rate range. This means that the provision of permanent tax incentives does not have the effect of 'equalizing' the existing differences in STRs between EU member states (corporate domiciles).

Additional analyses, (i) using two alternative ETR measures (one less sensitive to financial accounting differences between EU member states and one taking into account timing tax incentives as well), (ii) restricting our attention to those countries that already were a EU member state in 1990 and (iii) restricting our attention to those EU member states that had already adapted national law to the 7th EU company law directive on consolidated financial statements by 1990, do not change these findings.

\section{Motivation, average ETR measurement and accounting issues, previous research}

\subsection{Motivation and research question}

Statutory corporate tax rates differ between countries. This is the case in general, but also, perhaps surprisingly, within the European (economic) Union ${ }^{4}$. The last few years the intra-EU differences have given rise to increasingly active political discussions. The discussion is driven by the fact that taxes represent an actual cash outflow to companies and this can be expected to affect (i) the attractiveness of company formation in EU countries as well as (ii) location decisions of EU (and non-EU) companies. This creates both an interest of the various national governments for corporate tax policy and an interest in tax policy on the part of companies in order to be able to decide on their preferred domicile. 'Tax competition' between countries in the area of corporate taxes can focus on (i) the statutory tax rate (STR) and additionally on (ii) the provision of tax incentives, or tax subsidies, in various forms ${ }^{5}$. To measure the corporate tax rate effectively experienced by a company domiciled in a given country it is therefore necessary to measure the tax rate in that country inclusive of the tax incentives effects, i.e the effective, as opposed to statutory, tax rate (ETR).

The research question that this paper attempts to answer is the following: what effect does the provision of tax incentives have on actual corporate tax burden, compared to the STRs, in EU member states? In particular: do tax incentives affect the differences in actual corporate tax burden within the EU compared to the EU member state STRs? Note that both an increase in these differences and a decrease, or indeed a no-change result, would be 
consistent with tax incentives based tax competition between EU member states. That is, tax competion used tax incentives can have all three effects. This paper attempts to find out which effect is present.

A non-exhaustive, non-systematic, list of examples of tax incentives that would affect ETRs in EU member states is the following:

- the possibility of tax-loss carrybacks and carryforwards;

- fiscal unity arrangements (compensating losses and profits between companies in a group of companies);

- participation exemption arrangements (relief for the income of (possibly foreign) subsidiaries already taxed);

- investment tax incentives;

- research and development tax incentives;

- tax-free reserves arrangements (e.g. reserves for probable losses);

- different tax rates for capital gains;

- tax incentives related to company size (e.g. for small and medium sized companies);

- tax incentives related to regional location (e.g. for less-developed regions);

- tax incentives for co-ordination centers, corporate headquarters and distribution centers;

- employment tax incentives (e.g. tax incentives related to number of employees);

- tax incentives related to the training of personnel;

- asset related tax incentives (e.g. special depreciation arrangements for certain classes of assets);

- industry related tax incentives (preferential tax treatment for certain industries);

- age of company related tax incentives (differing tax rates and/or rules for new companies);

- tax incentives related to leverage (interest is corporate tax deductible, dividends are not).

Prior research has developed various ETR measures to measure corporate tax burdens taking into account tax incentives. Basically four (classes of) measures exist: (i) the effective marginal tax rate, (ii) the effective average tax rate, (iii) the financial accounting information based marginal effective tax rate, and (iv) the financial accounting information based average effective tax rate. We name the four classes of measures this way to avoid confusion. The original terminology used in the literature is slightly different. The important distinction is that (iii) and (iv) are based, completely or in part, on actual financial accounting data, whereas (i) and (ii) are based on an assumed typical investment project. We will briefly discuss each measure in turn. 
The effective marginal and the average tax rate are computed for a 'typical' investment project earning no economic rents (for the effective marginal tax rate) and assumed positive rents (for the effective average tax rate). In both cases the tax rate is the difference between the pre-tax-return and the post-tax return as a proportion of the post-tax return in a given country (tax jurisdiction) for the 'typical' project. Chennells and Griffith (1997, appendix A) provide a clear recent discussion of both measures.

In contrast, both the marginal and the average effective tax rate are calculated using actual firm financial statements. Graham (1996, p.189) conceptually defines the marginal effective tax rate in year $t$ for a company as "... the present value of [the current and] future tax obligation with earning one dollar of [taxable] income in year t". He discusses eight possible effective marginal tax rate measures found in the literature. All are at least in part financial statements based. The average effective tax rate, finally, can be broadly defined as taxes paid by a company in a fiscal year divided by financial accounting income (see, Graham (1996, p.195).

Callihan (1994, section 1), Collins and Shackelford (1995, pp.56-57) and Chennells and Griffith (1997, appendix A) all discuss the relative advantages of the different classes of ETR measures.

We measure the effect of domicile on corporate tax incentives in EU member states using the financial accounting information based average effective tax rate (average ETR), because our objective is to estimate the effect of tax incentives on the tax burden as it affects actual companies in the EU. As will become clear below, the average ETR purports to measure taxes payable, the cash outflow to the tax authorities for a given year, as a fraction of pre-tax financial accounting income.

\subsection{Average ETR measurement issues: accounting for corporate taxes and other accounting issues}

A problem with the determination of company average ETRs in EU member states is that not all member states make the distinction between income in company financial statements and company taxable income (book-tax difference). This is the case, to a varying degree, in the period considered in this paper, in (alphabetical order): Austria, Belgium, Finland, France, Germany, Greece, Italy, Luxemburg, Portugal and Sweden. The distinction does exist in the remaining five EU member states: Denmark, Ireland, The Netherlands, Spain and the UK (see, for more discussion, Hoogendoorn (1996)). 
However, the book-tax difference is primarily an issue at the legal entity level. Therefore, in this paper we will use consolidated financial statements ${ }^{6}$. In consolidated financial statements a distinction is made in all EU member states between consolidated financial accounting income and consolidated taxable income ${ }^{7}$.

The financial accounting background for the determination of the average ETR from financial statements is the following.

Two types of differences can exist between financial accounting income and taxable income. The first type are "timing differences". These are differences resulting from different timing moments in tax and financial accounts. These differences will exist as long as a certain item is included in the tax accounts but not in the financial accounts or the other way around. An example is a difference in the depreciation method used for a certain fixed asset in the two types of accounts. Tax laws might allow more rapid depreciation than financial accounting rules. In the end however, total depreciation will be the same for both sets of rules. So, after some time, the timing difference will start to reverse and at the end of the period there is no difference remaining. A sub-category of timing differences are "semi-permanent differences". These differences will exist as long as a company will continue (i) its operations in general or (ii) operating the tax-affected assets, and will not reverse during those periods. Examples are the use of different valuation methods (i.e. base stock) for inventory and differences in the treatment of asset (re)valuation in the financial and tax accounts.

The second type of differences are "permanent differences". These differences will never cease to exist, i.e. will never reverse, not even when the company is discontinued. This type of difference could for example arise when a company incurs expenses, which need no recognition in the calculation of taxable profit.

Note that timing and permanent differences affect the cash outflow to the tax authorities each year to a company and more particularly to its shareholders. Hence timing and permanent differences are the accounting representation of tax incentives, both timing and permanent tax incentives ${ }^{8}$.

Within the EU, financial accounting for corporate taxes in consolidated financial statements proceeds as follows. The matching principle requires that the corporate tax expense item in the financial statements should relate to the financial accounting income reported in those statements, i.e. requires 'interperiod tax allocation'. When financial accounting income is not equal to taxable income, taxes actually paid will not be equal to the tax expense. In the financial statements this book-tax difference can be 'accomodated' in two steps. First, permanent differences (incentives) are always excluded from the tax expense item 
in the financial statements. Second, using "interperiod tax allocation", temporary differences (incentives) are ex(in)cluded from (in) the tax expense item and this leads to a deferred tax liability (deferred tax asset) ${ }^{9}$. All EU countries use the matching principle for consolidated financial statements and thus in principle require recognition of the deferred tax liability/deferred tax asset.

All this shows that taxes payable for a company for a given year can be calculated from its financial statements by adjusting the tax expense item, which is already exclusive of permanent differences (incentives), for either the appropriation to the deferred tax liability (asset) or the change in the net deferred tax position ${ }^{10}$. This adjustement reflects the timing differences (incentives).

Permanent differences are not included in the EU in the financial accounting tax expense item in the consolidated financial statements. Hence, uniformly the tax expense in the consolidated financial statements in EU member states is exclusive of the permanent differences. In practice differences between EU member states in financial accounting for corporate taxes are possible, but they all concern timing differences. Examples of a lack of uniformity in accounting for timing differences between and within EU member states are (see also, Hoogendoorn (1996, table 3):

- a deferred tax asset is not recognized consistently because of the prudence principle or is netted against the deferred tax liability;

- 'partial' or 'full provison' for deferred taxes may be used;

- deferred taxes may be stated at their nominal or their present value;

- the 'liability' or the 'deferral' approach for dealing with (expected) tax rate changes may be used;

- deferred tax accounting for asset revaluation is not uniform.

However, we expect that these complications are less of a problem in the consolidated financial statements that we use. Note again that these 'complications' do not affect the accounting for permanent differences.

Apart from financial accounting for corporate taxes, notwithstanding intra-EU financial accounting harmonization efforts (the 4th and 7th Directives), other differences in prescribed financial accounting methods still exist. But again, this is a less important problem at the level of consolidated financial statements ${ }^{11}$. This is a second reason for restricting our analysis to consolidated financial statements in EU member states.

The above underlies the three ETR measures used below. In the first ETR measure we relate tax expense (which excludes permanent differences) to before tax financial accounting 
income. In the second ETR measure a company income measure is used that is less sensible to financial accounting differences between EU member states. In the third ETR measure we adjust the tax expense for timing differences.

Also, we use 7, 6 or 5 year panels (see below for explanation) of companies domiciled in the EU and calculate average ETRs for each company for the 7,6 or 5 year periods. Note that this will further alleviate the effect of lack of uniformity between EU member states in financial accounting for timing differences and of financial accounting in general, because of the reversal property of timing differences and of accrual accounting methods in general, on the ETR measures that we calculate.

\subsection{Average ETRs: prior cross-country research}

There exist a number of single-country financial accounting based average ETR studies. The studies that we are aware of using EU member state data are Holland (1998) for the UK, Janssen and Buijink (1998) for the Netherlands and Ballas and Hevas (1999) for Greece. The most recent single-country papers using US data are Gupta and Newberry (1997) and Plesko (1999). The last two papers provide references to earlier papers using US data.

In this section, however, we focus on the available comparative cross-country studies. Comparative cross-country ETR results are rare. We are aware of only Collins and Shackelford (1995) and Chennels and Griffith (1997).

Collins and Shackelford calculate average ETRs (adjusted for timing differences) for companies domiciled in Canada, Japan, the UK and the USA. They use the Global Vantage database, for a period from 1982 to 1991, resulting in a total of 30.037 company-year observations. Collins and Shackelford use all available companies each year whose financial statements pass a series of filters. They include companies with unconsolidated financial statements. Negative ETRs and ETRs $>0,70$ are truncated within the sample, i.e. set to zero and 0,70. Collins and Shackelford provide and analyse year-by-year results. One central finding, for both domestic-only and multinational companies, is that Japanese companies pay higher and Canadian companies pay lower percentages of financial accounting income in corporate tax (have higher (lower) ETRs) then do companies from the UK and the US. For 1991, the last year for which results are given, (truncated) mean average ETRs are (Collins and Shackelford, (1995, table 4)): 0,13 in Canada (205 companies), 0,53 in Japan (131 companies), 0,27 in the UK (634 companies) and 0,25 in the USA (2225 companies). They do not provide an explicit comparison with annual STRs in the four countries. 
Chennels, Griffith (1997) also use the Global Vantage database to calculate average ETRs (not adjusted for timing differences). They calculate these annually for the 1985 to 1994 period for 10 countries: Australia, Canada, France, Germany, Ireland, Italy, Japan, Spain, UK and the US. They report mean annual ETR only for companies whose ETR falls between 0 and $70 \%$. They also determine STRs annually for the countries studied. For 1994, the last year for which they give results, STRs, (truncated) mean ETRs and number of observations are: Australia $(0,33 ; 0,31 ; 23)$, Canada $(0,343 ; 0,306 ; 4)$, France $(0,333 ; 0,32 ; 25)$, Germany $(0,522 ; 0,271 ; 24)$, Ireland (n.a)., Italy $(0,532 ; 0.209 ; 2)$, Japan $(0,509 ; 0,403 ; 47)$, Spain $(0,35 ; 0,234 ; 4)$, UK $(0,33 ; 0,287 ; 73)$ and the US $(0,393 ; 0,333 ; 161)$ (Chennels and Griffith (1997, appendices C to L, various tables)). Note the small number of observations in a number of countries.

We give results below that are directly comparable to the Collins and Shackelford and Chennels and Griffith findings for a larger group of countries (compared to both studies) and larger company samples per country (compared to Chennels and Griffith).

\section{Methodology: measurement of the average ETR and sample}

\subsection{Average ETR}

We measure the average ETR in three different ways. Section 2.2. provides the financial accounting background. We define the ETRs in the context of the Worldscope financial statement template and its terminology.

Our first measure, ETR1, is income taxes (tax expense) divided by financial accounting pretax income before minority interest income, equity in earnings and extraordinary income. Extraordinary income is presented net of tax in the Worldscope template, as is equity in earnings of non-consolidated subsidiaries. The inclusion of minority interest income (i.e. its non-elimination) is conventional in this literature. ETR1 'picks up' permanent tax incentives. Income taxes are worldwide income taxes. ETR1 is comparable to the accounting based ETR measure used in Chennels and Griffith (1997). It is also used frequently in country specific ETR research.

As we explained earlier ETR1 is potentially affected by inter-country differences in accrual financial accounting practices between EU countries. This may be this case even though we work with consolidated financial statements and given European financial accounting harmonization. We therefore also calculate, as a first sensitivity check, a second ETR measure less affected by differences in financial accounting practices between countries. An obvious candidate would be a measure with operating cash flow. i.e operating income 
before non-cash expenses, as denominator. However, cash-flow statement data are not uniformly available on the Worldscope CD-ROM, especially in the earlier years of the period we consider. We therefore use the income statement item net sales as the denominator for our second ETR measure, ETR2 (again using income taxes as the numerator).

As a second sensitivity check we also calculate ETR3. In ETR3 income taxes adjusted for the net change in the deferred tax taxes (balance sheet item) is the numerator and financial accounting pretax income before minority interest (income), equity in earnings (from unconsolidated subsidiaries) and extraordinary income, is the denominator. ETR3 'picks up' both permanent and timing tax incentives. ETR3 is directly comparable to the main ETR measure used in Collins and Shackelford (1995). ETR3 is also used frequently in previous country specific research.

Table 1 gives our three ETR measures in terms of the Worldscope financial statement template terminology and item codes.

\section{Table 1}

\subsection{Sample}

The sample we use is a panel of all active [filter 3: inactive status companies], non-financial [filter 4: SIC codes 60, 61, 63 (financial companies) and filter 5: non-industrial financial statement template (i.e 'other' financial companies)] whose consolidated financial statements [filter 1: consolidation status] are available on the Worldscope CD-ROM in all years from 1990 to 1996 (inclusive). Of course, only companies with domicile in one of the current 15 EU member states were selected [filter 2]. Note that Worldscope's coverage is restricted to listed firms.

For all three ETR measures we only retain companies [filter 6] for which all dataitems necessary are avaliable in all seven years. A 7th filter removes for all three measures observations $><2$ s.d. from the mean (outliers).

The year 1996 was the latest year available on the Worldcope CD-ROM that we used and 1990 the first year (except for ETR3 for which 1991 is the first year for which results can be calculated).

Table 2 provides details about the initial sample selection. Our initial panel (filters 1, 2, 3, 4 and 5) consists of 2958 companies in EU member states with data for 7 years, i.e. 20706 company-years in all. The use of filters 6 and 7 leads to a panel of 2118 companies (14826 company-years) for which ETR1 can be determined, of 2083 companies (14581 
company-years) for ETR2, and of 1393 companies (8358) company-years for ETR3 (6 year panel). The adjustment for deferred taxes in ETR3 (i) makes 1991 the first year for which results can be given, but also (ii) leads to considerable loss of company panels due to loss of observations in the last year 1996. We therefore also created a second ETR3 panel (ETR3 (5 year panel) for the period 1991-1995, consisting of, after filters 6 and 7, of 1628 companies (8140 company years).

\section{Table 2}

Table 3 provides the number of companies in the sub-panel for each of the EU member states and the corresponding number of company-years, for each of the ETR measures. As can be seen for Luxemburg and Greece the number of company-years available is relatively small for ETR1 and ETR2. This is also the case for those two countries and for Austria and Sweden for ETR3 (6 year panel and 5 year panels), but not for Greece for the ETR3 for the 5 year panel ${ }^{12}$.

\section{Table 3}

\section{Results}

\subsection{Statutory tax rates (STRs) in EU member states}

We use various sources to determine the STRs in the EU member states between 1990 and 1996. Table 4 provides an overview of the annual STRs in the EU member states for a number of years. A number of member states, notably France, Germany and Ireland have multiple corporate tax rates.

It is not immediately obvious how to determine the average STR in each EU member state for the 1990-1996 period. We determine the average STR for each country in two ways. In table 4 the unweighted average STR for each country is the simple average, assuming a $50 \%$ pay-out ratio for countries (years) with a split-rate system. For the weighted average STR in table 4 the weights are the total pre-tax income for all companies in the ETR1 sample each year and additionally the relative amount of pre-tax income distributed in countries (years) with a split-rate system. In Ireland the weights are based on the number of companies in the sample in qualifying industries and their total pre-tax income. The STRs in table 4 were calculated disregarding differential capital gains tax rates and differential tax rates for 'low' 
profits that exist(ed) in a number of countries. Of course, in countries were STRs were the same in all 7 years, unweighted and weighted STR are equal.

As can be seen in table 4 the average STRs (both unweighted and weighted) are in the thirty to fifty percent region. The top three STRs are in (1) Italy, (2) Germany, and (3) Belgium, whereas the lowest rates are found in Greece, Sweden and Ireland. The correlation between unweighted and weighted STRs is high: Pearson correlation coefficient 0,97. Below we will use the weighted STR and provide additional results for the unweighted STR.

\section{Table 4}

\subsection{Average ETRs in EU member states}

The total panel of 2118 companies for ETR1 has been subdivided in 15 subpanels, one for each EU member state. For each country panel of companies, ETR1s are calculated for each company as the average ETR1 for the period 1990-1996. The results are shown in table 5.

\section{Table 5}

As explained earlier the ETR1 results in table 5 are on a filtered panel basis. The panel for each country was filtered by removing outlying observations with an ETR1 which outcentered the average ETR1 for the panel by more than two standard deviations.

Table 5 shows that, except for Denmark, the mean and median ETR1 are quite close. We will focus ${ }^{13}$ on median ETR1 below as our preferred measure of the corporate tax burden in a EU member state. Focussing on the median results then, table 5 shows that ETRs in EU member states are highest in Germany, Italy and Luxemburg, lowest in Austria, Portugal and Ireland.

EU member states can also be ranked on the basis of the size of differences between STR (weighted average) and median ETR1 to show the effects of tax incentives. Table 6 provides the ranking.

\section{Table 6}

The table shows that on average in the EU the median ETR1 is almost 10 percentagepoints below the STR. There are, however, considerable differences between the different EU member states. Whereas Sweden and France have a median ETR1 less then 2 percentage- 
points below their STR, Austria, Belgium and Portugal have a median ETR1 of around 20 percentage below their STR.

However (cfr. our research question in section 2.1.), the provision of tax incentives does not lead to ETRs being more equal between EU member states than the STRs.

Here, and below, we use the coefficient of variation (CV (standard deviation/mean)) as a simple metric to measure the relative variability in STRs and ETRs between EU member states. The CV of weighted STR (in table 4) is below the coefficient of variation of the filtered median ETR1 (in table 5): 19,1\% versus 26,6\%. Hence, corporate effective tax burdens (ETR1) do not differ less between countries than do corporate STRs. The provision of tax incentives does not make corporate tax burdens in the EU more equal compared to STRs.

\section{Additional analyses}

\subsection{Alternative ETRS}

A problem with the ETR1 scores for different EU member states is the potentially confounding influence of differences in financial reporting practices between the member states. As we explained earlier we therefore also calculated ETR2 with a denominator less susceptible to financial accounting practice differences. Net sales is used as denominator, which 'eliminates' all between-EU country expenses accounting related differences. The result, (filtered) median ETR2 for the 1990-1996 period, is shown in table 7.

\section{Table 7}

The CV for median ETR2 in table 7 is also higher than the CV for STR (table 5): $51,8 \%$ vs. $19,1 \%$. However, the Pearson correlation coefficient between median ETR 1 (table 5) and median ETR 2 (table 7) is only 0,44, indicating that ETR1 and ETR2 do not rank EU member states consistently. Hence, part of the ETR1 differences between countries may be attributable to financial accounting differences. On the other hand, as we explained earlier, ETR2 as defined here is not the ideal 'financial accounting differences free' measure.

As a further sensitivity check we also calculated ETR3, which is ETR1 adjusted for the change in the (net) deferred tax liability. The results are also in table 7 . They show the filtered median ETR3 scores for each EU member state both for the 6 year panel and the 5 year panel in which 1996 is not used, i.e. for the 1991 - 1995 period. As explained earlier, in the 5 year panel loss of observations for the ETR3 is less severe. Overall median ETR3 and 
ETR1 (table 5) scores are similar. ETR3 is lower most of the time, as expected, indicating a slow reversal of temporary differences. Note that the 6 year panel ETR3 score for Luxemburg ( 1 observation, see table 3 ) is extreme. We will focus on the 5 year panel results therefore. Median ETR1 and ETR3 (5 year panel) also rank member states similarly, underscoring the results given earlier: Pearson correlation coefficient 0,88. Again, the CV of median ETR3 (5 year panel) is higher then that for STR (table 5): 30,7\% versus 19,1\%.

\subsection{STR}

Inspection of the CVs of unweighted average STRs (in table 4, before last column (coefficient of variation: 16,9\%)) and of median ETR1, ETR2 en ETR3 (5 year panel) already reported does not change the conclusions of the previous section.

\subsection{Different sets of countries}

We also calculated CVs for weighted STR and median ETR1 (both in table 5) for (i) the group of current EU member states that were already in the EU before 1990 (15 current member states minus Austria, Finland and Sweden) and (ii) the group of current EU members that had already adapted national law to the 7th EU company law directive on consolidated financial statements in 1990 (15 current member states minus Ireland, Italy, Finland, Portugal and Sweden). For the group of pre-1990 EU members CVs for STR and ETR1 are 19,7\% and $27,3 \%$. For the group of pre-1990 7th Directive adopters they are 13.0\% and 22,9\%. Again, in both cases, tax incentives appear to widen the differences in effective corporate tax burdens in the EU compared to the STRs.

\section{Concluding remarks}

This is the first study that attempts to measure actual corporate tax burdens for companies domiciled in all EU member states based on financial statement information.

Our main results are that (i) the provision of tax incentives, both those of a permanent and of a timing nature, differs substantially between EU member states and (ii) these tax incentives do not have the effect of equalizing actual corporate tax burdens in the EU, i.e. actual corporate tax burdens differ more between EU member states (company domiciles) than do the statutory tax rates.

As we explained, and this is limitation of our research, differences (i) in accounting for corporate taxation and (ii) in financial accounting in general between EU member states are 
problematic in the context of this paper. To address both problems we (i) used only consolidated financial statements, (ii) we calculated ETRs for several years and (iii) we provided additional results based on alternative ETR measures.

In this paper, and that constitutes a further limitation, we focussed on listed companies in EU member states. Results for ETRs of non-listed companies would potentially provide a more balanced picture of corporate tax burdens in the EU.

Finally, in future research it would also be interesting to look at the effects of differences in tax integration systems (e.g. classical vs. imputation) between corporate and shareholder level taxation of corporate profits in the EU for corporate tax rates in the EU. This paper did not address that issue. 


\section{Notes}

${ }^{1}$ Also called tax subsidies or tax preferences in the literature. We will use 'tax incentives' throughout.

${ }^{2}$ For a recent empirical study, see Devereux and Griffith (1998).

${ }^{3}$ We explain these notions, permanents and timing tax incentives, in more detail in section 2.2. below. In essence a permanent incentive leads to elimination of (part of) taxes payable and timing tax incentices to a deferral of (part of) taxes payable.

${ }^{4}$ In this paper we use data for the companies in the current 15 EU member states. The data used are for the years from 1990 to 1996. Of the current 15 EU member states 12 joined the EU before 1990. Austria, Finland and Sweden joined the EU in 1995. As a sensitivity check we will provide an analysis of the data of the 12 pre-1990 EU members.

${ }^{5}$ Alternatively, the statement here could be phrased referring to differences in the corporate tax base, i.e. taxable profits.

${ }^{6}$ The seventh EU company law Directive harmonised consolidated financial accounting in the EU. In 5 of the current 15 EU member states the seventh Directive was implemented after 1990; Finland in 1992; Ireland in 1992; Italy in 1991; Portugal in 1991; Sweden in 1995 (see Nobes and Parker (2000, table 5.7). As a sensitivity check we will also provide an analysis for the 10 pre-1990 seventh Directive adopters.

${ }^{7}$ Doumentation that underlies this remark for each of the 'no-book-tax difference' EU countries is in Maukner (1998, p.60) for Austria; in Jorissen and Maes (1996, p.921) for Belgium; in Järvenpää (1996,p.906) for Finland; in Hoareau (1998, p.112 ) for France; in Haller (1998, p.93) for Germany; in Caseley (1998, p.479) for Greece; in Zambon (1998, p. 194 ) for Italy; in Clark (1994. p.175) for Luxemburg; in Fernandes Ferreira (1998, p.829) for Portugal and in Heurlin and Peterssohn (1998, p.1109) for Sweden.

${ }^{8}$ To be precise, these are net tax incentives, i.e. a part of the permanent and timing differences may actually increase taxable income, ceteris paribus, i.e. are tax disincentives.

${ }^{9}$ An alternative treatment is to ignore the book-tax difference. The advantage of this "flow-through accounting" treatment is simplicity. The disadvantage of the method is that is does not adhere to the matching principle.

${ }^{10}$ Actually, this is an estimate of that amount, see Plesko (1999), this is further complication.

${ }^{11}$ As Nobes and Parker (2000, p.88) conclude: "The seventh Directive has achieved a significant degree of harmonization in group accounting [within the EU]".

${ }^{12}$ Note that different panel length (6 year vs. 5 year) leads to considerable changes in the number of observations available in the countries in table 3.

${ }^{13}$ Focussing on the median results for the filtered data provides extra assurance that outlying observations, e.g. as in the case of Denmark, do not affect the results. 


\section{References}

Alexander, D. and Archer, S. (eds) (1998) European accounting guide. San Diego: Harcourt Brace \& Company.

Ballas, A. and Hevas D. (1999) 'Determinants of the cross section variability in corporate effective tax rates: some further evidence', paper presented at the 22nd annual congress of the EAA, Bordeaux.

Callihan, D.S. (1994) 'Corporate effective tax rates: a synthesis of the literature', Journal of Accounting Literature, 13: 1-43

Caseley, R. (1998) 'Greece', in Alexander, D. and Archer, S. (eds) European accounting guide. San Diego: Harcourt Brace \& Company, pp.462-521.

Chennells, L. and Griffith, R. (1997) Taxing profits in a changing world. London: Institute for Fiscal Studies.

Clark, P. (1994) Luxembourg. London, Routledge.

Cnossen, S. (1996) 'Reform and harmonization of company income tax systems in the European Union', Research Memorandum 9604, OCFEB, Erasmus Universiteit Rotterdam

Collins, J. and Shackelford, D. (1995) 'Corporate domicile and average effective tax rates: the cases of Canada, Japan, the United Kingdom and the United States', International Tax and Public Finance, 2: $55-83$.

Coopers \& Lybrand (1998) 1998 International tax summaries: a guide for planning and decisions. New York: Coopers \& Lybrand Global Tax Network/Wiley.

Devereux, M. and Griffith, R. (1998) 'Taxes and the location of production: evidence from a panel of US multinationals', Journal of Public Economics, 68: 335-367.

Easson, A. (1993) Taxation in the European Community. London: Athlone Press.

Fernandes Ferreira, L. (1998) 'Portugal', in Alexander, D. and Archer, S. (eds) European accounting guide. San Diego: Harcourt Brace \& Company, pp.796-877.

Graham, J (1996) 'Proxies for the corporate marginal tax rate', Journal of Financial Economics, 42: 187-221.

Gupta, S. and Newberry, K. (1997) 'Determinants of the variability in corporate effective tax rates: evidence from longitudinal data', Journal of Accounting and Public Policy, 16: 1-34.

Haller, A. (1998) 'Accounting in Germany', in Walton, P., Haller, A. and Raffournier, B. (eds) International accounting. London: International Thompson, pp.78-107.

Heurlin, S., Pettersohn, E. (1998) 'Sweden', in Alexander, D. and Archer, S. (eds) European Accounting Guide, San Diego: Harcourt Brace \& Company, pp.1076-1131.

Hoareau, C. (1998) 'Accounting in France', in Walton, P., Haller, A. and Raffournier, B. (eds) International accounting. London: International Thompson, pp.108-129.

Holland, K. (1998) 'Accounting policy choice: the relationship between corporate tax burdens and company size', Journal of Business Finance and Accounting, 25: pp. 265-288. 
Hoogendoorn, M (1996) 'Accounting and taxation in Europe: a comparative overview', European Accounting Review, 5: 783-794.

Janssen, B. and Buijink, W., 'Determinants of the variability of corporate effective tax rates (ETRs): evidence for the Netherlands', paper presented at the 21st annual congress of the EAA, Antwerp.

Järvenpää, M. (1996) 'The relationship between taxation and financial accounting in Finland', European Accounting Review, 5: 899-914.

Jorissen, A. and Maes, L. (1996) 'The principle of neutrality: the cornerstone of the relationship between financial reporting in Belgium', European Accounting Review, 5: 915-931.

Maukner, H., (1998) 'Austria' in Alexander, D. and Archer, S. (eds) European Accounting Guide, San Diego: Harcourt Brace \& Company, pp.29-98.

Messeree, K. (1993) Tax policy in OECD countries: choices and conflicts. Amsterdam: IBFD.

Nobes, C. and Parker, R. (2000) Comparative international financial accounting. Harlow: Pearson Education.

OECD (1991) Taxing profits in a global economy: domestic and international issues. Paris: OECD.

Plesko, C. (1999) 'An evaluation of alternative measures of corporate tax rates', working paper, MIT.

Teixeira, G. (1997) Taxing corporate profits in the EU: a comparison of the Portuguese, British and Dutch systems. London: Kluwer Law International.

Tirard, J.M. (1994) Corporate taxation in EU countries. London: Longman.

Walton, P., Haller, A. and Raffournier, B. (eds) (1998) International accounting. London: International Thompson.

Zambon, S. (1998) 'Accounting in Italy', in Walton, P., Haller, A. and Raffournier, B. (eds) International accounting. London: International Thompson, pp.181-215. 
Tables

Table 1: Effective tax rate (ETR) measures.

\begin{tabular}{lll}
\hline ETR measure & $\begin{array}{l}\text { Numerator/Denominator } \\
\text { (terminology Worldscope) }\end{array}$ & Worldscope item codes \\
\hline ETR1 & income taxes / pre-tax income & $01451 / 01401$ \\
ETR2 & income taxes / net sales & $01451 / 01001$ \\
ETR3 & $\begin{array}{l}\text { income taxes }-\left(\text { deferred taxes }_{\mathrm{t}}-\text { deferred taxes }_{\mathrm{t}-1}\right) / \\
\text { pre-tax income }\end{array}$ & $01451-\left(03263_{\mathrm{t}}-03263_{\mathrm{t}-\mathrm{t}}\right) /$ \\
& & 01401 \\
\hline
\end{tabular}

Table 2: Sample selection.

\begin{tabular}{|c|c|}
\hline Country & $\begin{array}{l}\text { Number of companies } \\
\text { (panel) }\end{array}$ \\
\hline $\begin{array}{l}\text { Companies domiciled in EU member states with consolidated } \\
\text { financial statements available in Worldscope database }\end{array}$ & 5180 \\
\hline Less: companies with inactive status & 1093 \\
\hline Less: SIC codes $60,61 \& 63$ (financial companies) & 606 \\
\hline $\begin{array}{l}\text { Less: companies with a non-industrial template (other financial } \\
\text { companies) }\end{array}$ & 523 \\
\hline $\begin{array}{l}\text { Available companies in initial panel (after filters 1-5) (company- } \\
\text { years) }\end{array}$ & $2958(20706)$ \\
\hline $\begin{array}{l}\text { Available companies in panel for ETR1 } 1^{\mathrm{a}} \text { (after filters } 6 \text { and 7) } \\
\text { (company-years) }\end{array}$ & $2118(14826)$ \\
\hline $\begin{array}{l}\text { Available companies in panel for ETR } 2^{\mathrm{b}} \text { (after filters } 6 \text { and } 7 \text { ) } \\
\text { (company-years) }\end{array}$ & $2083(14581)$ \\
\hline $\begin{array}{l}\text { Available company-years for ETR } 3^{\mathrm{c}}\left(6 \text { year }^{\mathrm{d}} \text { panel) (after filters } 6\right. \\
\text { and 7) (company years) }\end{array}$ & $1393(8358)$ \\
\hline $\begin{array}{l}\text { Available company-years for ETR } 3^{\mathrm{c}}\left(5 \text { year }^{\mathrm{d}} \text { panel) (after filters } 6\right. \\
\text { and 7) (company years) }\end{array}$ & $1628(8140)$ \\
\hline
\end{tabular}

${ }^{\mathrm{a}}$ ETR $1=$ income taxes/pre-tax income

${ }^{\mathrm{b}} \mathrm{ETR} 2=$ income taxes/net sales

${ }^{c}$ ETR3 $=$ income taxes $-\left(\right.$ deferred taxes $_{t}-$ deferred taxes t $\left._{\mathrm{t}-1}\right) /$ pre-tax income

${ }^{\mathrm{d}}$ As explained in the text for ETR3 we use 6 and 5 year panels 
Table 3: Number of companies in panel and total company-years for effective tax rate (ETR) calculations for European Union member states (1990-1996, 1991-1996/1995 for ETR3).

\begin{tabular}{|c|c|c|c|c|}
\hline EU member states & ETR1 $^{a}$ & ETR2 $^{b}$ & $\begin{array}{l}\text { ETR3 }^{\mathrm{c}} \\
\text { (6 year panel) }\end{array}$ & $\begin{array}{l}\text { ETR3 }^{\mathrm{c}} \\
(5 \text { year panel) }\end{array}$ \\
\hline Austria & $39(273)$ & $37(259)$ & $1(6)$ & $1(5)$ \\
\hline Belgium & $50(350)$ & $52(364)$ & $21(126)$ & $35(175)$ \\
\hline Denmark & $101(707)$ & $96(672)$ & $76(456)$ & $88(440)$ \\
\hline Finland & $69(483)$ & $75(525)$ & $29(174)$ & $36(180)$ \\
\hline France & $289(2023)$ & $276(1932)$ & $149(894)$ & $178(890)$ \\
\hline Germany & $319(2233)$ & $317(2219)$ & $41(246)$ & $57(285)$ \\
\hline Greece & $5(35)$ & $5(35)$ & $4(24)$ & $23(115)$ \\
\hline Ireland & $40(280)$ & $35(245)$ & $41(246)$ & $42(210)$ \\
\hline Italy & 27(189) & $25(175)$ & $16(96)$ & $47(235)$ \\
\hline Luxembourg & $5(35)$ & $5(35)$ & $1(6)$ & $2(10)$ \\
\hline The Netherlands & $123(861)$ & $123(861)$ & $112(672)$ & $119(595)$ \\
\hline Portugal & $32(224)$ & $32(224)$ & $32(192)$ & $36(180)$ \\
\hline Spain & $84(588)$ & $79(553)$ & $61(366)$ & $78(390)$ \\
\hline Sweden & $103(721)$ & 101(707) & $1(6)$ & $1(6)$ \\
\hline United Kingdom & $832(5824)$ & $825(5775)$ & $808(4848)$ & $885(4425)$ \\
\hline $\begin{array}{l}\text { Total number of companies } \\
\text { (company -years) }\end{array}$ & $2118(14826)$ & 2083(14581) & $1393(8358)$ & $1628(8140)$ \\
\hline
\end{tabular}


Table 4: Statutory corporate tax rates (STR) (including local taxes) (\%) in European Union member states* (1990 -1996).

\begin{tabular}{|c|c|c|c|c|c|c|c|c|c|}
\hline Country & 1990 & 1991 & 1992 & 1993 & 1994 & 1995 & 1996 & $\begin{array}{l}\text { Uw.avg }{ }^{\mathrm{a}} \\
\text { STR }\end{array}$ & $\begin{array}{l}\text { W. avg }{ }^{b} \\
\text { STR }\end{array}$ \\
\hline Austria & 39 & 39 & 39 & 39 & 34 & 34 & 34 & 36.86 & 36.02 \\
\hline Belgium & 43 & 39 & 39 & 39 & 40.17 & 40.17 & 40.17 & 40.07 & 40.28 \\
\hline Denmark & 40 & 38 & 38 & 36 & 34 & 34 & 34 & 36.29 & 35.78 \\
\hline Finland & 40.2 & 40.2 & 40.2 & 34.1 & 28 & 28 & 28 & 34.10 & 34.02 \\
\hline France & $\begin{array}{l}\mathrm{RE}^{\mathrm{c}}: 37 \\
\mathrm{DP}^{\mathrm{d}}: 42\end{array}$ & $\begin{array}{l}\text { RE: } 34 \\
\text { DP: } 42\end{array}$ & 33.33 & 33.33 & 33.33 & 36.67 & 36.67 & $35.83^{\mathrm{e}}$ & 34.70 \\
\hline Germany & $\begin{array}{l}\text { RE: } \\
56.5 \\
\text { DP: } \\
44.3\end{array}$ & $\begin{array}{l}\text { RE: } \\
56.5 \\
\text { DP: } \\
44.3\end{array}$ & $\begin{array}{l}\text { RE: } \\
58.1 \\
\text { DP: } \\
45.5\end{array}$ & $\begin{array}{l}\text { RE: } \\
56.5 \\
\text { DP: } \\
44.1\end{array}$ & $\begin{array}{l}\text { RE: } 54.9 \\
\text { DP: } 42.6\end{array}$ & $\begin{array}{l}\text { RE: } 54.9 \\
\text { DP: } 42.6\end{array}$ & $\begin{array}{l}\text { RE: } 56 \\
\text { DP: } 42\end{array}$ & $49.90^{\mathrm{e}}$ & 50.05 \\
\hline Greece & $\begin{array}{l}\text { RE: } 46 \\
\text { DP: } 0\end{array}$ & $\begin{array}{l}\text { RE: } 46 \\
\text { DP: } 0\end{array}$ & $\begin{array}{l}\text { RE: } 46 \\
\text { DP: } 0\end{array}$ & 35 & 35 & 35 & 35 & $29.86^{\mathrm{e}}$ & 32.53 \\
\hline Ireland & $\begin{array}{l}43 \\
Q^{f}: 10\end{array}$ & $\begin{array}{l}43 \\
\text { Q: } 10\end{array}$ & $\begin{array}{l}40 \\
Q: 10\end{array}$ & $\begin{array}{l}40 \\
\text { Q: } 10\end{array}$ & $\begin{array}{l}40 \\
\text { Q: } 10\end{array}$ & $\begin{array}{l}38 \\
\text { Q: } 10\end{array}$ & $\begin{array}{l}38 \\
\text { Q: } 10\end{array}$ & $28.69^{\mathrm{g}}$ & $21.94^{\mathrm{g}}$ \\
\hline Italy & 46 & 47.8 & 47.8 & 52.2 & 52.2 & 53.2 & 53.2 & 50.34 & 50.48 \\
\hline Luxemburg & 39.4 & 39.4 & 39.4 & 39.4 & 39.4 & 39.4 & 39.4 & 39.4 & 39.4 \\
\hline Netherlands & 35 & 35 & 35 & 35 & 35 & 35 & 35 & 35 & 35 \\
\hline Portugal & 39.6 & 39.6 & 39.6 & 39.6 & 39.6 & 38.8 & 38.8 & 39.37 & 39.29 \\
\hline Spain & 35.3 & 35.3 & 35.3 & 35.3 & 35.3 & 35.3 & 35.3 & 35.3 & 35.3 \\
\hline Sweden & 30 & 30 & 30 & 29 & 28 & 28 & 28 & 29 & 28.54 \\
\hline UK & 34 & 34 & 33 & 33 & 33 & 33 & 33 & 33.29 & 33.35 \\
\hline
\end{tabular}

* The sources used for this table are: Cnossen (1993), Coopers \& Lybrand (1998), Easson (1993), Messeree (1993), OECD (1991), Teixeira (1997) and Tirard (1994).

${ }^{a}$ Uw. avg = unweighted average of the statutory tax rates for the 1990-1996 period

${ }^{\mathrm{b}} \mathrm{W}$. avg = weighted average, taking into account relative profits per year and the distinction between the RE and DP tax rates where applicable, for the 1990-1996 period

${ }^{\mathrm{c}} \mathrm{RE}$ gives corporate tax on retained earnings

${ }^{\mathrm{d}}$ DP gives corporate tax on distributed profits

e assuming a proportion of retained earnings/distributed profits of 50/50

${ }^{\mathrm{f}} \mathrm{Q}$ gives corporate tax on qualifying companies: i.e. manufacturing companies, manufacturing services, international financial services, trading operations in Shannon airport, repair and maintenance of aircraft, ships and computer equipment, film production, engineering services for projects outside Ireland and organic production

${ }^{\mathrm{g}}$ companies allocated to either tax regime based on SIC industry code 
Table 5: Statutory tax rates (STR) and and mean (s.d.) and median (interquartile range) effective tax rates ((filtered) ETR1) for European Union member states (1990-1996) (\%).

\begin{tabular}{|c|c|c|c|c|c|}
\hline Country & STR $^{\mathrm{a}}$ & mean ETR1 ${ }^{b}$ & $\begin{array}{l}\text { standard } \\
\text { deviation }\end{array}$ & median ETR1 $^{b}$ & $\begin{array}{l}\text { interquartile } \\
\text { range }\end{array}$ \\
\hline Austria & 36.02 & 19.72 & 16.55 & 17.67 & 27.62 \\
\hline Belgium & 40.28 & 21.64 & 23.35 & 20.99 & 24.63 \\
\hline Denmark & 36.02 & 14.82 & 91.18 & 29.40 & 18.38 \\
\hline Finland & 34.02 & 25.28 & 40.46 & 29.82 & 23.26 \\
\hline France & 34.70 & 28.45 & 40.84 & 32.82 & 17.38 \\
\hline Germany & 50.05 & 33.61 & 31.51 & 38.53 & 29.25 \\
\hline Greece & 32.53 & 19.79 & 5.97 & 20.85 & 11.60 \\
\hline Ireland & 21.94 & 13.78 & 9.75 & 13.86 & 19.24 \\
\hline Italy & 50.48 & 30.66 & 16.06 & 35.32 & 23.58 \\
\hline Luxemburg & 39.4 & 35.81 & 20.32 & 34.09 & 30.50 \\
\hline Netherlands & 35 & 26.84 & 13.59 & 31.80 & 17.88 \\
\hline Portugal & 39.29 & 16.89 & 17.23 & 17.19 & 29.38 \\
\hline Spain & 35.3 & 22.90 & 13.44 & 24.11 & 17.10 \\
\hline Sweden & 28.54 & 27.01 & 20.93 & 27.47 & 21.24 \\
\hline UK & 33.35 & 25.98 & 15.91 & 29.00 & 16.14 \\
\hline
\end{tabular}

${ }^{\text {a }}$ Statutory tax rates (weighted STR) are taken from last column of table 4

${ }^{\mathrm{b}}$ ETR1 $=$ income taxes/pre-tax income 
Table 6: European Union member states ranked by the difference between statutory tax rate and effective tax rate ((filtered) median ETR1)(1990-1996).

\begin{tabular}{lll}
\hline Rank & Country & $\begin{array}{l}\text { STR }^{\mathrm{a}} \text {-ETR1 }^{\mathrm{b}} \\
\text { difference }\end{array}$ \\
\hline 1 & Sweden & 1.07 \\
2 & France & 1.88 \\
3 & Netherlands & 3.20 \\
4 & Finland & 4.20 \\
5 & United Kingdom & 4.35 \\
6 & Luxemburg & 5.31 \\
7 & Denmark & 6.38 \\
8 & Ireland & 8.08 \\
- & AVERAGE EU & 9.58 \\
9 & Spain & 11.19 \\
10 & Germany & 11.52 \\
11 & Greece & 11.68 \\
12 & Italy & 15.16 \\
13 & Austria & 18.35 \\
14 & Belgium & 19.29 \\
15 & Portugal & 22.10 \\
\hline
\end{tabular}

${ }^{\text {a }}$ Statutory tax rates (weighted STR) are taken from last column of table 4

${ }^{\mathrm{b}}$ ETR1 is taken from before last column of table 5 
Table 7: Effective tax rates (filtered median ETR2 and filtered median ETR3) for European Union member states (1990-1996 (1991-1996 or 1991-1995 for ETR3) (\%).

\begin{tabular}{llll}
\hline Country & Median ETR2 & Median ETR3 $^{\mathrm{b}}$ & Median ETR3 $^{\mathrm{c}}$ \\
\hline Austria & 0.83 & 13.64 & 13.64 \\
Belgium & 1.19 & 23.56 & 26.83 \\
Denmark & 0.95 & 23.54 & 23.86 \\
Finland & 1.02 & 27.49 & 26.68 \\
France & 1.43 & 31.72 & 32.28 \\
Germany & 1.08 & 36.21 & 38.14 \\
Greece & 1.66 & 23.18 & 23.67 \\
Ireland & 1.10 & 12.58 & 12.85 \\
Italy & 2.56 & 37.35 & 34.77 \\
Luxemburg & 3.69 & 68.35 & 40.24 \\
Netherlands & 1.25 & 31.37 & 31.36 \\
Portugal & 0.84 & 16.97 & 18.30 \\
Spain & 1.23 & 23.45 & 22.29 \\
Sweden & 0.92 & 18.68 & 18.68 \\
UK & 1.76 & 28.28 & 27.53 \\
\hline
\end{tabular}

${ }^{\mathrm{a}} \mathrm{ETR} 2=$ income taxes/net sales

${ }^{\mathrm{b}}$ ETR3 $=$ income taxes $-\left(\right.$ deferred taxes $\mathrm{s}_{\mathrm{t}}-$ deferred taxes $\left.\mathrm{s}_{\mathrm{t}}\right) /$ pre-tax income, six year panel

${ }^{c}$ ETR3 $=$ income taxes $-\left(\right.$ deferred taxes $s_{t}-$ deferred taxes $\left.s_{t}\right) /$ pre-tax income, five year panel 